\title{
Fairy-tales and father Freud. Is psychoanalysis the right tool to understand folk imaginary?
}

\author{
Ioana Repciuc
}

Ioana Repciuc - Ph.D, Researcher, A. Philippide Institute of Romanian Philology, Iași

\begin{abstract}
The paper reviews the bibliography in the field of psychoanalytical analyses of fairy tales since the instrumental works of Sigmund Freud to today's approaches. Folk and fairy tales as well as mythological narratives were analyzed by the proponents of the psychoanalytic study of fairy tales through two main approaches: the psychoanalyst could either analyze the fairy tale creator's psychology, or examine the psychological motivations underneath the fairy tale's characters narrative behavior. From the post-Freudians and post-Jungians to feminist revisionists, the recent fairy tale scholarship is apparently losing its connection with the actual content of these texts created according to a certain worldview and folk imaginary.
\end{abstract}

\section{KEYWORDS:}

Psychanalysis, fairy tale, Sigmund Freud, Carl Gustav Jung, folklore, feminism.

\section{INTRODUCTION}

Fairy tales were one of the first items studied by folklore scholars at the begining of the field itself; it was the massive editorial work of the Brothers Grimm who attracted the world's attention to folk literature. Today more than ever, fairy tales authored by bestselling personalities (J.R.R. Tolkien, C.S. Lewis, J.K. Rowling), together with the classic collections of Charles Perrault or Hans Christian Andersen, have become a popular mass-mediated product, flooding the shelves of bookstores and successfully adapted by the movie industry. It is also widely accepted that the main audience targeted by these texts was children and youth, many educators recommending them also for their psychological benefits. Folklore scholarship pointed out often that the important distinction between fairy tale and folktale is many times effaced, though it is a meaningful one when studying the origins and paths of development of a certain text in either folklore, oral tradition, and folk heritage, or in popular culture or printed literature: "Folk and fairy tales are generally confused with one another and taken as make-believe stories with no direct reference to a particular community or historical tradition. Their own specific ideology and aesthetics are rarely 
(1)

seen in the light of a diachronic historical development which has great bearing on our cultural self-understanding" (Zipes 1979, 5). Scholars frequently use "folktale" to refer to tales from oral tradition and "fairy tale" to designate the written tales. In functional terms, some experts emphasized that fairy tales were told as pure entertainment, others insisted on their role in instruction and socialization, in projecting a better society and modeling strategies for survival and empowerment (Haase 2008, 324).

After a century and a half of great popularity enjoyed by folk texts, materialized by large research projects studying and drafting typologies and folk narrative repertories (see Aarne, Thompson 1961), the beginning of the $20^{\text {th }}$ century saw the folk and fairy tale becoming the topic of more diverse types of analysis; they were conducted by folklorists, anthropologists, sociologists, psychologists or literary critiques, with the most important ones focused on formalist, structuralist, historical or ritualist theories. The next step in the evolution of the fairy tale exegesis was the understanding of fairy tales as a "connective tissue between a mythological past and the present realities" (Warner 2014, XV). The fairy tale content stops being the subject of research for its own and becomes an object by which the critics examine their favorite theories. Cultural and political historians, Freudians, Jungians, Marxists, structuralists and postmodernists find in the folk texts an appropriate field for identifying their own theoretical and ideological views.

\section{FAIRY TALES ON THE ANALYST'S COUCH}

Myths and fairy tales received special attention from psychoanalytic theory since Sigmund Freud used the story of Oedipus to illustrate and name his controversial theory about infant desire. The most important connection between folklore or mythology and psychoanalysis was the collaborative work of Freud and Oppenheim about the relationship between dreams, myths and their connection with psychoanalysis. The connection between dreams and myths or fairy tales was already discussed even before by Edward Clodd in his volume Myths and Dreams, published in 1889. The part-time Victorian folklorist from Suffolk employed an evolutionary framework influenced by Darwin and Tylor and emphasized the incapacity of "savages" to distinguish between the living and the not living, and between dream and reality (Clodd 1891, 13), but his work was generally ignored.

A more popular theory was authored by L. Laistner, an early literary comparatist, who, in his Das Räthsel der Sphinx, published in 1889 , tried to demonstrate that fairy tales were created during nightmares. Only a year after the publication of Freud's The Interpretation of Dreams, a German folklorist, Friederich von der Leyen, publicized the idea that these texts were nothing but narrated dreams (apud Tatar $2003,53)$. The dream theory was also favored by one of the most important early Romanian folklorists, a theory that was considered at the time of its popularization within Romanian intellectual circles as "the new theory on the formation of fairy tales". In his monographic study on the fairy tale published in 1893, Bogdan Petriceicu Hasdeu attempted to explain that the "literature of dreaming" is basically transposed in fairy tale. Even though his demonstration stressed almost the same arguments as Clodd's, the Romanian scholar does not quote any of the contemporary theorists who were moving in the same direction, but instead admits being inspired from philosophical sources such as the Neoplatonism and Schopenhauer. It is worth mentioning that Hasdeu does mention in his essay the important contribution of Alfred Maury on the understanding of the state of 
dreams (Hasdeu 2008, 367-376) - a theory that was indeed influential to Freud himself.

Ernst Oppenheim was a student of classical mythology and literature, a professor teaching Greek and Latin in Vienna, who attended Freud's university lectures in 1906; as a sign of his interest in psychoanalysis Oppenheim dedicated to the father of psychanalysis a paper on classical mythology where he used Freud's methods, and then sent the published version to the dedicatee in 1909. Oppenheim's scholarly gift impressed Freud especially due to the fact he was himself already convinced of the importance of studying the relation between psychanalysis and mythology: "I have long been haunted by the idea that our studies on the content of the neuroses might be destined to solve the riddle of the formation of myths, and that the nucleus of mythology is nothing other than what we speak of as 'the nuclear complex of the neuroses" (Freud, Oppenheim 1957, 1718).

Being always aware that the work done in connection with mythology by him and his disciples (Otto Rank or Karl Abraham) was still rather amateur, because they did not have the necessary „knowledge of antiquity”, Freud believed that Oppenheim was the right collaborator to put his experience of studying the classics in the service of psychoanalysis (Freud, Oppenheim 1957, 17). The manuscript written by Freud in 1911 would afterwards be completed by Oppenheim with some comments and notes, but not published until 1957. It was the only paper of such length that Freud did not publish during his lifetime, a situation also determined by Oppenheim's decision to detach himself from mainstream psychoanalysis and to follow alternative paths.

But before the text devoted to the analysis of dreams as fairy tales co-authored with Oppenheim, Freud impacted cultural hermeneutics first and foremost by The
Interpretation of Dreams. Freud's important distinction between "manifest dream-content" and "latent dream-thoughts" allowed a new understanding of the hidden meanings of cultural artifacts other than dreams of individuals, namely myths, rituals, fairy tales, works of arts. This new "hermeneutics of deceit" with wide-reaching consequences for text analysis is also influenced by Freud's emphasis on the relevance of the art creator's personal life and psychology for which it is especially revealing his Psychopathology of Everyday Life written in 1901 (Doty 2000, 160-161).

The scholars who drew inspiration from Freud's theory were especially his followers and disciples, which applied the Freudian point of view explicitly and precisely. Besides Oppenheim, Freudian analysis of myths was undertaken by Otto Rank, Géza Róheim, and Karl Abraham. A representative of the classic Freudian paradigm, Otto Rank, applied Freud's theory in The Myth of the Birth of the Her, published in German in 1909; the Austrian therapist explains the saga stories as representations of the child's revolt against the parents' domination. A more complex work on myths and symbols was done by the Hungarian psychologist and anthropologist Géza Róheim, a scholar who had the advantage of using the Freudian instruments on actual tribal rites of initiation he himself discovered on the field in Australia (Róheim 1945). With the help of these native data, Róheim goes further than Freud and his disciples in stating the analogy between dream and folk tale or myth: "It seems that dreams and myths are not merely similar but that a large part of mythology is actually derived from dreams. In other words, we can not only apply the standard technique of dream interpretation in analyzing a fairy tale but can actually think of tales and myths as having arisen from a dream, which a person dreamed and then told to others, who retold it 


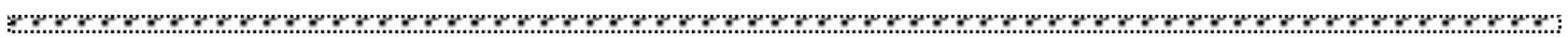

again, perhaps elaborated in accord with their own dreams" (Róheim 1953, 394). Finally, Karl Abraham, one of the most important of Freud's disciples, wrote in 1912 an interpretation of the spiritual activities of the Egyptian Pharaoh Amenhotep IV (Abraham 1935).

Besides the Freudian classic approaches, the other school of thought devoted to psychological interpretation of fairy tales was the Jungian one; representatives of this research trend made use of Jung's analytical psychology and his method of uncovering the individual and collective unconscious, while rejecting Freud's theory of infantile sexuality. Developing a more inclusive approach to mythology than Freud, the Swiss psychiatrist studied the process of individuation in the fairy tales plot and particularly analyzed the archetypal patterns in their deep structure. The most important disciple and follower of Carl Gustav Jung in this line of analysis was Marie-Louise von Franz, who devoted many of her studies to applying the Jungian methods of fairy tale analysis. She especially put an emphasis on the relationship between anima and animus, and self-realization in the narrative development of fairy tales. She also used her actual clinical practice experiences to explain some elements in fairy tales. Her lifework interested was accomplished by the monumental three-volume The Symbolism of the Fairy Tale (1952-1957), co-authored with Hedwig von Beit. Another follower of the Jungian approach was Joseph Campbell, who applied the Jungian symbolism to understanding mythical stories and folktales. His most important work in this field is The Hero with a Thousand Faces (1949), in which he investigates the psychological insights of the life adventure narratives using the archetypal-hero pattern so widely present in fairy tales worldwide.

After the time of the classic Freudians analysis on myths and fairy tales, the evolution of orthodox psychoanalytic movement into a medical specialty determined that "the interest in applying psychoanalytic theory outside of a therapeutic setting seems to have diminished" (Fischer 1963, 238). The post-Freudian analysists - the ones which followed restrictively and less monolithically his theory - came from different fields of study, especially because of the limitations and polarization of the founder's main theories. Major anthropologists such as A.L. Kroeber or Clyde Kluckhohn made limited use of psychanalysis in their research dealing with native societies. However, anthropologists and mythologists alike tended generally to mistrust the involvement of psychological terms into their research, but it is well known that this anti-psychological bias actually prevailed among scholars of any discipline in the humanities and social sciences (Jones 1965, 89). For example, Lewis Spence, an early mythologist studying animism and traditional narratives wrote in his $A n$ Introduction to Mythology: "The theories of Freud and his followers as to religion and the origin of myth have not been considered, since, in the writer's opinion, they are scarcely to be taken seriously" (Spence 1921, $5)$. This mistrust in the revolution of the humanities and social sciences brought by Freud's interpretation was interpreted unsurprisingly by its advocates in psychological terms, i.e. as the unavoidable resistance of humans in front of the experience of getting to know their deepest side (Kristeva 1997, 19).

Overall, we cannot deny that the disciplines of psychology and anthropology have influenced each other during the last half of the twentieth century even while maintaining some of the mutual suspicion. As an analyst observes, "the psychological disciplines are variously influential upon the anthropological: cognitive, behavioral, and 
(1) culture-and-personality psychology, psychoanalysis, psychiatry, and ethnopsychology have all had periods of influence" (Doty 2000, 189-190).

According to the main research views exhibited by the proponents of the psychoanalytic study of fairy tales, there are two main approaches being expressed: the psychoanalyst could either analyze the fairy tale creator's psychology, or examine the psychological motivations underneath the fairy tale's characters narrative behavior.

The most important and also the most provocative and well-read study on the topic of fairy tales studied with psychoanalytic tools belonged to Bruno Bettelheim. In his The Uses of Enchantment: The Meaning and Importance of Fairy Tales (1976), Bettelheim aimed to demonstrate that fairy tales help children to overcome the Oedipus complex and handle the rivalry with siblings. Many different streams of critique were risen by Bettelheim; the feminist critics undermined his competence for "uncritically using the sexist tools of Freudian psychoanalysis", while folklorists for "being ignorant of the variations and sociohistorical contexts that are central to understanding the evolution and transmission of folktales and fairy tales" (Jorgensen 2008, 779).

The most rigorous researcher of fairy tales in a psychanalytic framework was a professional folklorist - Alan Dundes, one of the most important of the last century. Though a proponent of using psychanalysis in folklore, Dundes manifests himself against the dream theory, pointing out that "unlike individual dreams, folktales must appeal to the psyches of many, many individuals if they are to survive" (Dundes 1976, 1501). Living aside the dream theory, he believed that "much of the meaning of folkloristic fantasy is unconscious" (Dundes 1976, 1503), and relied on the process of projection (between characters, and between narrator and the characters). He also believed in the importance of using fairy tales for the child's psychological development. When interpreting Little Red Riding Hood, he emphasized the protagonist's unconscious fantasies. Even though Dundes did advocate for employing Freud's theory in understanding folklore, the folklorist was also aware of the mistake of making psychoanalysis the only tool for a correct and rich analysis of myths and fairy tales. Such a restrictive approach cannot truly evaluate folklore material, he believed. Making an effort to avoid such a mistake, Dundes took Freud's suggestion that mythology is psychology projected upon the external world in studying American Indian cosmogonic conceptions (Dundes 1962, 1037). Like Dundes, Bengt Holbek, in his Interpretation of Fairy Tales: Danish Folklore in a European Perspective (1987) also understands that a broad and universal use of psychology in analysis fairy tales is dangerous and inaccurate, so he uses only some psychological concepts which he introduced in a larger folkloristic approach.

In 1991, a year after Bettelheim's suicide, Dundes also expressed his views on how folklore should be studied with psychanalytic tools while reviewing the very popular work of Bettelheim. Admitting Bettelheim's merits in bringing Freudian readings of fairy tales to the attention of the general public, the folklore scholar proves how the author fails to observe conventional academic etiquette, namely he neither quotes the work already done in this field nor uses quotation marks when he actually does (Dundes 1991, 81). Similar to Dundes' conception was Edmund Leach's one. The renowned British social anthropologist employed psychanalysis to understand the magical symbolism of hair, and discovers that the insight offered by Freud's view should always be complemented with anthropological and sociological 
methods (Leach 1958, 161). It is important to notice the existence of fairy tale scholars who saw no practical reason for applying psychological tools in their analysis only because "there is no psychology in a fairy tale. The characters have little interior life; their motives are clear and obvious" (Pullman 2000, 12).

The most active alternative strain of psychological interpretations of fairy tales comes in the last decades from one of the most important students of the folk narrative field, Jack Zipes, who became widely known for his complete and revised edition of the classic Brothers Grimm collection. After strongly criticizing Bettelheim's approach and his many shortcomings, Zipes preferred to take Jacques Lacan's theory about the gaze in his studies. He is nevertheless the only one making use of this theory; another important name in the Lacanian analysis of fairy tales is Shuli Barzilai (1999). In many of his books devoted to fairy tales, Zipes uses psychanalysis in connection with the feminist critique. His feminist bias obliged him to follow restrictively the classic psychanalytical theories, namely to avoid the patriarchalist stance that they projected according to feminist critics. Zipes' exegesis was meant to provide a less repressive view on gender roles than the one actually displayed in the majority of most known fairy tales' plots. In his Recent Psychological Approaches with Some Questions about the Abuse of Children, he highlights the defective violence and trauma displayed by fairy tales, which is not beneficial to children's development. The same path was followed by Maria Tatar in Fairy Tales and the Art of Subversion: The Classical Genre for Children and the Process of Civilization (1983). Though influenced herself by Freudian and Jungian theories, Tatar was more careful about taking the symbols in fairy tales as universal, as the Jungian scholars did, for example.

\section{FAIRY \\ TALES \\ PSYCHOANALYSTS AND FEMINISTS}

Though Freud was apparently avoided and criticized by early feminists due to the fact that much of his theory promoted a misogynist worldview which was the obvious continuation of the patriarchal milieu dominating the beginning of the century in Europe, his theoretical accomplishments were later recognized and put into practice by feminist psychologists and therapists. Feminist theorists admitted that "Freud did not get fully engaged with an exploration of feminine sexuality, not only because of his sexist prejudices and his chronic cancer, but also because there is .an intellectual problem inherent in the exercise. The pathological indicates the formal with which it is on a continuum. Psychoanalysis deals above all with symptoms. However, femininity and masculinity are not symptoms, and nor are they pathologies" (Mitchell 2000, XXXII).

Therefore, against all odds, the so-called feminist revisionists of fairy tales - a strong countercultural movement that has dominated fairy tale scholarship in the last decades were strongly associating themselves with psychoanalytical theories and tools. The feminist revisions of fairy tales and myths came into existence in the 1970 s and the 1990s, with the two waves being heavily connected with one another. Among the most popular pieces of this literature, we can cite Anne Sexton's Transformations (1971), Olga Broumas's Beginning with $O$ (1977), and Angela Carter's The Bloody Chamber (1979). These authors based their themes and characters on the ones provided by classic fairy tales, rewriting them in such a way as to emphasize the oppressed female seeking liberation, empower heroines, and attenuate the alleged male aggression.

The revisionists came into close contact with contemporary feminist psychoanalytic theories by "making visible women's lived 
(n)

experiences, often using the metaphor/ symbol of the mirror, (...) exploring relationships between women, especially the relationships between mothers and daughters (...) presenting women's stories as central to our understanding of humanity" (Schanoes 2014, 3). Being two rather marginalized or neglected perspectives taken into account by professional folklorists, feminism and psychanalysis have a lot in common: The feminist paradigm employed in folkloristics is "concerned with eliminating distortions in our cultural lenses, with reviewing our culture from new angles, and in taking off our cultural blinders in the study of women's folk culture that forms such an important part of human culture" (Mitchell 1993, 278). Using feminist ideology together with psychanalytical instruments became therefore a useful research path. For example, Jay Mechling, an important social anthropologist, uses psychanalysis to explain the social construction of masculinities and to deconstruct the "the misogyny and homophobia in much male lore" (Mechling 2005, 225).

Given the strong impact of feminist theory in the American academic world, fairy tale criticism became visibly dominated by this type of analysis. This trend of thought became a steady path in folklore analysis also due to its early start in the 1970s in American folkloristics. The interdisciplinary paths which are either post-Freudian or postJungian (Chodorow 1978; Doty 2000) termed "feminist psychoanalysis", "post-Freudian mythography", "psychosociology" (Slater 1996), or "psychoantropology" (Ingham 1996). The emphasis starts to be not on understanding the social and cultural meanings of fairy tales, but on the role played by women in these texts, with an emphasis on the need to change the traditional worldview naturally displayed by them. As one of the recent scholars in this field admits, "feminist revisions of fairy tales and myths and feminist scholarship/theory participate in a continuous and dynamic dialogue about feminine subjectivity" (Schanoes 2014, 14). The abovementioned folklore scholar and Germanist Jack Zipes also described the relationship between fairy-tale revisions and fairytale scholarship/theory. His well-praised volume Fairy Tale as Myth/Myth as Fairy Tale (1994) was treated as a source of theory and terminology by feminist revisionists; Zipes explains that the fairy tale revising process is meant to "articulate new values and beliefs, incorporate the critical and creative thinking of the producer of the revision and alter the reader's views of traditional patterns, images, and codes" (Zipes 1994, 9).

Zipes, a fairy-tale expert in both editing and commenting this special textual category, is a prolific author in this new wave of postmodern directions of research by denouncing the socio-psychological and political dynamics behind the allurement of fairy tales. In the opinion of this analyst, the fairy tale was heavily and unwillingly instrumentalized by capitalistic and aristocratic ideologies: "As pre-capitalist art form, the folktale presents, in its partiality for everything metallic and mineral, a set and solid, imperishable world. This imperishable world can be linked to concepts of medieval patriarchalism, monarchy, and absolutism, particularly in the seventeenth and eighteenth centuries in Germany" (Zipes 1979, 29). It is nucessary, Zipes advocates, that we free the fairy and folk tales from the ideological subversion undertaken by the higher social classes and the culture industry that undermined their emancipatory value. For example, it was the Grimm brothers' manipulation that pointed out to the "sexist values" and "Puritan ethos" in the story of Cinderella (Zipes 1979, 177).

Many other authors devoted entire volumes to the production of gender and the 
(1)

reinforcement of patriarchal structures that fairy tales expose. Marina Warner focuses, in her From the Beast to the Blonde, on the image of women in some classic fairy tales. Christina Bacchilega is interested in "how the narrative construction and manipulation of the tale of magic contribute to making different ideological effects possible within specific historical and social contexts" (Bacchilega 1997, 8). Analyzing Little Red Riding Hood, she explains the fairy tale's plot within a gender framework: "The literary tradition of 'Red Riding Hood' therefore does lock the protagonist into a gendered and constricting chamber. Whether she survives her journey into the outer world or not, the girl is inside when the tale ends - inside the wolf's belly for Perrault, or her grandmother's home for the Grimms. Devoured or domesticated, charged with sin or in charge of the feminine hearth, in the literary fairy-tale tradition Red Riding Hood is subjected to the laws of one deliberative masculine body. When the wolf punishes the girl's curiosity, and when the hunter saves her and the grandmother, males determine feminine limits" (Bacchilega 1997, 58-59). Other interpretations belonging to psychologists or psychoanalysts only undertake the analysis from their field's point of view to enhance the literary significance of the fairy tale (Barchilon 1959).

Though generally praised by most of his colleagues and readers, some folklore scholars pointed out that Zipes' type of analysis does not actually fit into the field of folklore: "All the shortcomings of Zipes' book as a piece of folkloristic research may derive from the fact that Zipes' work is not really about folktales or folklore" (Swann Jones 1982, 244).

\section{IS THIS THE RIGHT TOOL TO UNDERSTAND FOLK IMAGINARY?}

The contemporary landscape of fairy tale scholarship creates the impression that many of its exponents surrendered to the enticing prospect of transforming the fairy tale into a multivalent intertext able to correspond to each of their theories, ideologies, and paths of interpretations. While this is the risk taken by any immemorable cultural artifact and comes unavoidably with the popularity of these products of culture, this unfortunately takes us far away from the actual content of these texts to only deconstructed and reconstructed versions of them. It becomes apparent for folklore scholarship that even fairy tale research that is expected to be useful and interesting for the benefit of the domain loses ground in front of the more popular and politically correct trends, and the fairy tale becomes a free-for-all token in any analytic experiment, as one of the advocates of this direction acknowledges: "Fairy tales come to reflect the fluctuating experience of modernity (...) and most importantly, the agency of the subject in a modern consumer society" (Martin 2007, 40).

Fairy tales were indeed the subject of multiple theories and interpretations, and experienced the tendencies of scholars to choose extreme positions according to their own preferred instruments and research views. As for the psychoanalytically oriented critics, they tended to view fairy tales as mere symbolic transcriptions of psychic processes. Even more than that, as Maria Tatar noticed, the fact that "psychoanalytic critics rarely agree on the symbolic meaning of an object or a figure in a tale is also not designed to inspire confidence in their methods" (Tatar 2003, 54). Psychoanalysis adepts as well as feminist critics deciphered in characters and situations symbols of sexual desires and constructions of sexuality.

Scholars like Dundes and Holbek warned though against the dangers of using only one set methods while expelling the others. Also J.L. Fischer, an adept of psychological anthropology, explained that "overemphasizing psychological 
(n) considerations and ignoring sociological ones are considered important for children's hardly needs to be stressed to most anthropologists. Psychologists or others can use uniformities in the folktales of different peoples as evidence about general human nature, but it is not possible to gain a complete understanding of specific folktales in this way, since the many differences between bodies of folktales of different peoples remain unexplained" (Fischer 1963, 240). Jeana Jorgensen also underlined that "these interpretations can privilege one version of a tale over all others, thus silencing the polyvocality that makes folktales and fairy tales such potent narrative forms. Other interpretations are illuminating for their capacity to explain the otherwise unexplainable mysteries of these tales. On the whole, psychological approaches are stimulating and thought provoking, much like the phenomena they try to explicate" (Jorgensen 2008, 782).

Besides the many controversies in the psychology of fairy tales, it is noticeable that one concerns the question of whether fairy tales are instruments of transmitting or of refuting worldviews for the next generation. development described by Fischer - cognitive (educating the members of the society about the world, nature, social rules), affective (providing wish-fulfillment and catharsis), and conative (binding the individual more closely to his/her society) (Fischer 1963, 255258) - was recognized by many education experts as good reason to recommend them as literature for children (see the recent trend in Romanian pedagogy: Lörincz 2010, 69-70; Pană 2012, 50). On the opposite side, others stressed that the atrocities in the fairy tales' plots, or the fact women are always presented as sole agents of evil, or weak beings, most of the time left at the mercy of men, made them rather unsuitable to children's knowledge (Tatar 2003). The fact that fairy tales could be considered useful for understanding specific psychological disorders or even treating them (Zegreanu 2012, 128-129), as Freud and early psychiatrists certainly did, should not be confused with making the psychological or psychanalytical view a serious method in understanding the cultural imaginary displayed by these texts.

The psychological functions of fairy tales that

\section{ACKNOWLEDGMENTS AND DISCLOSURES}

The author has no potential conflict of interests to disclose.

\section{REFERENCES}

1. Aarne, Thompson (1961): Antti Aarne, Stith Thompson, The Types of the Folktale: A Classification and Bibliography, FF Communications 184. Helsinki, Academia Scientiarum Fennica.

2. Abraham (1935): Karl Abraham, Amenhotep IV. Psycho-analytical Contributions Towards the understanding of his Personality and of the Monotheistic Cult of Aton, in "The Psychoanalytic Quarterly", Volume 4, Issue 4, pp. 537569.

3. Bacchilega (1997): Christina Bacchilega, Postmodern Fairy Tales. Gender and Narrative Strategies, Philadelphia, University of Pennsylvania Press.

4. Barchilon (1959): Jacques Barchilon, Beauty and the Beast From Myth to Fairy Tale, in "The Psychoanalytic Review", 46 (4), pp. 19-29.

5. Barzilai (1999): Shuli Barzilai, 'Grandmother, what a dreadfully big mouth you have!' Lacan's Parables of the Maternal Object, in Lacan and the Matter of Origins, Stanford, Stanford University Press, pp. 199-226.

6. Broumas (1977): Olga Broumas, Beginning with O, New Haven, Yale University Press.

7. Carter (1979): Angela Carter, The Bloody Chamber and Other Stories, London, Gollancz. 
(1)

8. Clodd (1891): Edward Clodd, Myths and Dreams, Second Edition, revised, London, Chatto \& Windus

9. Doty (2000): William G. Doty, Mythography. The Study of Myths and Rituals, Second Edition, Tuscaloosa \& London, The University of Alabama Press.

10. Dundes (1962): Alan Dundes, Earth-Diver: Creation of the Mythopoeic Male, in "American Anthropologist", New Series, Vol. 64, No. 5, Part 1 (Oct., 1962), pp. 1032-1051.

11. Dundes (1976): Alan Dundes, Projection in Folklore: A Plea for Psychoanalytic Semiotics, in "MLN", Vol. 91, No. 6, Comparative Literature (Dec., 1976), pp. 1500-1533.

12. Dundes (1991): Alan Dundes, Bruno Bettelheim's Uses of Enchantment and Abuses of Scholarship, in "Journal of American Folklore", vol. 104, No. 114, Winter 1991, pp. 74-83.

13. Fischer (1963): J.L. Fischer, The Sociopsychological Analysis of Folktales, in "Current Anthropology", Vol. 4, No. 3 (Jun., 1963), pp. 235-295.

14. Freud, Oppenheim (1958): Sigmund Freud and D. E. Oppenheim, Dreams in Folklore, New York.

15. Haase (2008): Donald Haase, Fairy Tale, in Donald Haase (ed.), The Greenwood Encyclopedia of Folktales and Fairy Tales, 3 vols., London, Greenwood Press, pp. 322-325.

16. Hasdeu (2008): Bogdan Petriceicu Hasdeu, Folcloristica, vol. I, edited by I. Oprisan, Bucharest, Saeculum I.O.

17. Ingham (1996): John M. Ingham, Psychological Anthropology Reconsidered. Pubs. of the Soc. for Psych. Anth., 8. New York: Cambridge UP

18. Jones (1965): Ernest Jones, Psychoanalysis and Folklore, in The Study of Folklore, edited by Alan Dundes, New Jersey, Prentice-Hall, pp. 88-102.

19. Jorgensen (2008): Jeana Jorgensen, Psychological Approaches of Folktales and Fairy Tales, in Donald Haase (ed.), The Greenwood Encyclopedia of Folktales and Fairy Tales, 3 vols., London, Greenwood Press, p. 778-782.

20. Kristeva (1997): Julia Kristeva, La révolte intime. Pouvoirs et limites de la psychanalyse, Paris, Fayard.

21. Leach (1958): Edmund R. Leach, Magical Hair, in "Journal of the Royal Anthropological Institute”, 88/2, pp. 147-64.

22. Lörincz (2010): Cristina Lörincz, Din nou despre basm: De la magie la pragmatism, Braşov, Tipotex.

23. Martin (2007): Ann Martin, Red Riding Hood and the Wolf in Bed. Modernism's Fairy Tales, Toronto, University of Toronto Press.

24. Mechling (2005): Jay Mechling, The Folklore of Mother-Raised Boys, in Manly Traditions. The Folk Roots of American Masculinities, edited by Simon J. Bronner, with an afterword by Alan Dundes, Bloomington, Indianapolis, University of Indiana Press, pp. 211-227.

25. Mitchell (1993): Carol Mitchell, Feminist Lenses and Female Folklore, in Feminist Theory and the Study of Folklore, edited by Susan Tower Hollis, Linda Pershing, and M. Jane Young, Urbana and Chicago; University of Illinois Press, pp. 277-284.

26. Mitchell (2000): Juliet Mitchell, Psychoanalysis and feminism. A radical reassessment of Freudian Psychoanalysis, Basic Books, New York.

27. Pană (2012): Elena Pană, Valori formative ale literaturii pentru copii. Aplicații didactice la basm, Slatina, Didactic Press.

28. Pullman (2000): Philip Pullman, Fairy Tale from the Brothers Grimm: A New English Version, London, Penguin Classics.

29. Róheim (1945): Géza Róheim, The Eternal Ones of the Dream: A Psychoanalytic Interpretation of Australian Myth and Ritual, New York, International UP.

30. Róheim (1953): Géza Róheim, Fairy tale and dream, in "The Psychoanalytic Study of the Child", Volume 8, Issue 1, pp. 394-403.

31. Schanoes (2014): Veronica L. Schanoes, Fairy tales, myth, and psychoanalytic theory: feminism and retelling the tale, Farnham, Burlington, Ashgate.

32. Sexton (1971): Anne Sexton, Transformations, Boston, Houghton Mifflin.

33. Slater (1966): Philip E. Slater, Microcosm: Structural, Psychological, and Religious Evolution in Groups. New York, Wiley.

34. Spence (1921): Lewis Spence, An introduction to mythology, New York, Farrar \& Rinehart.

35. Swann Jones (1982): Steven Swann Jones, Breaking the Magic Spell: Radical Theories of Folk and Fairy Tales by Jack Zipes, in "Western Folklore", Vol. 41, No. 3 (Jul., 1982), pp. 240-244.

36. Tatar (2003): Maria Tatar, The Hard Facts of the Grimms' Fairy Tales, Princeton, Princeton University Press.

37. Warner (1994): Marina Warner, From the Beast to the Blonde: On Fairy Tales and Their Tellers, London, Chatto \& Windus. 
Bulletin of Integrative Psychiatry $\bigcirc$ New Series O September 2019 ○ Year XXV ONo. 3 (82)/101 Fon 38. Warner (2014): Marina Warner, Once Upon a Time. A short history of fairy tale, Oxford, Oxford University Press.

39. Zegreanu (2012): Gianina Zegreanu, Semnificaţii simbolice în basm, Cluj-Napoca, Napoca Star.

40. Zipes (1979): Jack Zipes, Breaking the Magic Spell. Radical Theories of Folk and Fairy Tales, Austin, University of Texas Press.

41. Zipes (1994): Jack Zipes, Fairy Tale as Myth/myth as Fairy Tale, Lexington, University of Kentucky Press.

\section{Corespondence:}

Ioana Repciuc,

$\mathrm{PhD}$, Researcher, A. Philippide Institute of Romanian Philology, Romanian Academy - Iași

Branch, Bulevardul Carol I, nr. 8, Iași, 700505, repciuc_i_o@yahoo.com

Submission: 27 jun 2019

Acceptance: 27 aug 2019 